\title{
EDITORIAL NOTES AND NEWS
}

To teachers of English and of Latin, as well as to those who engage in propaganda for or against either subject as an educational instrument, we recommend a careful perusal of a lecture delivered in February by Dr. J. W. Mackail to the Leeds and District Branch of the Classical Association, now published as The Alliance of Latin and English Studies (London, John Murray, Is. net). 'In an age of increasing specialisation, at a time given over to the pursuit of short-cuts and the invention of substitutes, when the weight of accumulated knowledge, already greater than can be borne, is multiplying almost daily, can we recover that grasp of the unity of learning which is at once the symbol and the substantiation of a sense of the unity of life? If so, it is clear that the first thing to be done is to discard bodily the idea of competition in studies, and replace it by the idea of their co-operation and mutual reinforcement.' Leaving to those engaged in teaching and organisation the consideration of means and methods, Dr. Mackail pleads with his usual grace and power for the correlation of English and Latin studies in the interest of both subjects and of humane education.

J. T. S. writes :

The Oxford Rhesus was delightful, partly because of the charming setting in the garden of New College, with barbaric tents for the
Trojan encampment and noble medieval ruins for the walls of Troy. At night the shadows and the impending darkness may have added a touch of mystery, a suggestion of real war and tragedy. In the afternoon the sunshine, the green glades, and the trees, together with the not unpleasing but distracting music of the Oxford bells, kept one happily aware that all was makebelieve. These gracious people, who talked and sang of war and night-adventure, danger and cunning, loyalty and death, were happy children of the fancy, not real men, sweating for destiny. That would have been a pity if the play had been Medea or Hippolytus; for the Rhesus it seemed right. The play has interest and beauty, but no tragic tension. Even pathos is hardly felt until the lamentation of the Muse at the end turns fantasy into high poetry. The skill of Mr. Cyril Bailey and his actors, helped by the setting and the music, contrived to give the whole play, not the last scene only, poetic value. Hector's gallant bearing-perhaps a shade more gallant than the text suggests-the languid grace of Rhesus-more modest, perhaps, than the author intended-and Athena's pleasant combination of majesty and mischief, remain in the memory. For the sake of the total impression we should have liked a touch of poetry in Dolon, though his comedy was in itself excellent; and we think Odysseus and Diomede might have been given harder outlines, more sharply contrasted with the Trojan chivalry and vagueness. But nearly all the details seemed to us right, and the producer had his reward in the complete success of the final scene, superbly sung and acted by the Muse. Had the earlier scenes been presented as crude melodrama the end might have seemed a purple patch, and the whole incoherent. As it was, the performance gave us a new and, we think, true interpretation of the spirit of a very graceful poem.

A notice of the performance of the Birds at King's College, Strand, will appear in our next issue.

\section{THE REVERSE OF ARISTOTLE.}

-Peripeteia : a sudden change of fortune or reverse of circumstances.' - New Eng. Dict.

THE word peripeteia has done long and strenuous service. Critics from the Renaissance to Mr. Walkley, historians from Polybius to Mr. John Buchan, have never wearied of the golden term -everything, in fact, is known about it, except perhaps its meaning, or, rather, its meanings; for its uses, by Aristotle in dramatic criticism, and by later writers as a general term, are, I think, quite different and distinct. The traditional rendering, 'a reversal of for- tune' or 'tragic catastrophe,' fits Polybius and other post-Aristotelian authors; but it has made nonsense for centuries in the Poetics.

This is, of course, no new theory. Over half a century ago it was suggested by Vahlen, who had himself been anticipated to some extent by Pye in I792. Yet in England, at all events, this view has strangely failed to take hold. Butcher faces both ways, and Bywater will have none of it. Some of the arguments that follow are, I find, not new, but a good deal of the evidence 